\title{
Sikap Mahasiswa Muslim terhadap Perkembangan Marketplace
}

\author{
Fairuz Aulia Shabrina $^{1 *}$, Nida Fitria ${ }^{2)}$, Rifki Candra Nugraha ${ }^{3)}$ \\ ${ }^{1,2,3}$ Fakultas Pendidikan Matematika dan Ilmu Pengetahuan Alam, Universitas Pendidikan Indonesia \\ *Email korespondensi: fairuzauliashabrina@ upi.edu
}

\begin{abstract}
The purpose of writing this article is to describe the attitudes of Muslim students towards Marketplace developments. The background of this research is that the development of technology is very rapid, causing many fields to be affected by its development. Which one of them is technology in the field of information and communication technology. Internet is born which makes every business easier. One thing that is affected is in the economic sector, especially in the buying and selling process. The presence of the internet has created a place for online transactions called the Marketplace. Currently the Marketplace is very popular with people. Then what is the attitude of Indonesian Muslim students in facing all of this, what is the impact on Muslim students. In this study we used the literature study method, spread out questionnaires and interviews. The results of this research are expected to be taken into consideration in determining attitudes towards Marketplace developments. For future researchers, it is hoped that they can research with a wider time and reach so that the results obtained are more representative.
\end{abstract}

Keywords : Marketplace, transaction, economics

Saran sitasi: Shabrina, F. A., Fitria, N., \& Nugraha, R. C. (2021). Sikap Mahasiswa Muslim terhadap Perkembangan Marketplace. Jurnal Ilmiah Ekonomi Islam, 7(01), 275-284. doi:http://dx.doi.org/10.29040/jiei.v7i1.1602

DOI: http://dx.doi.org/10.29040/jiei.v7i1.1602

\section{PENDAHULUAN}

Dimaklumi secara luas, Islam adalah agama yang dianut oleh mayoritas penduduk Indonesia (Arif, 2012). Islam merupakan agama yang telah disempurnakan oleh Allah SWT. Sesuai dengan firman Allah dalam surat Al-Maa-idah ayat 3 yang artinya "telah aku sempurnakan untukmu agamamu, dan telah aku cukupkan kepadamu nikmat-Ku, dan telah aku ridhai Islam sebagai agama bagimu..." [AlMaa-idah:3]. Islam sebagai agama yang sempurna telah mencakup segala aspek kehidupan manusia, yang dijadikan pedoman hidup manusia agar dapat memperoleh kebahagiaan dunia dan akhirat. Salah satu aspek yang diatur dalam islam adalah yang berhubungan dengan bidang ekonomi. Atau sering disebut dengan ekonomi islam.

Saat ini kemajuan teknologi sudah berkembang dengan pesat. Teknologi adalah aktivitas atau kajian yang menggunakan pengetahuan sains untuk tujuan praktis dalam industir, pertanian, perobatan, perdagangan dan lain-lain (Nuryana, 2018). Hal ini mengakibatkan banyak kegiatan yang dilakukan dengan memanfaatkan internet atau dilakukan secara online. Kegiatan-kegiatan yang dilakukan secara online ini sangat digemari oleh masyarakat karena dapat menghemat waktu, uang, tenaga, dan manfaat lainnya. Tak terkecuali pada bidang jual-beli yang juga dilakukan secara online. Kegiatan jual-beli secara online ini sangatlah populer di kalangan masyarakat karena dirasa dapat mempermudah kegiatan jual-beli. Kegiatan ini difasilitasi oleh aplikasi yang dinamakan Marketplace.

Penggunaan Marketplace dalam kegiatan jual beli online atau yang biasa disebut dengan $e$ commerce yang sangatlah digemari oleh masyarakat Indonesia ini tenyata memiliki banyak manfaat, bukan hanya bagi penggunanya, namun juga bagi perekonomian Indonesia. E-commerce merupakan salah satu pendorong utama yang menjadikan Indonesia sebagai negara dengan nilai ekonomi digital terbesar di Asia Tenggara mencapai \$40 miliar pada tahun 2019 dan diprediksi meningkat hingga \$130 
miliar pada tahun 2025. Sehingga dengan banyaknya retail toko dan konsumen yang beralih ke e-commerce, pertumbuhan perekonomian Indonesia dapat ditingkatkan lebih jauh. Namun dibalik banyaknya manfaat penggunaan Marketplace, banyak juga kekurangannya yang jarang kita sadari. Penggunaan Marketplace memang dapat membantu pertumbuhan perekonomian Indonesia dan juga mempermudah penggunanya, namun apakah kegiatan ini dapat membantu mensejahterakan kehidupan seluruh rakyat Indonesia? Oleh karena itu pelaksanaan jual-beli online perlu diatur oleh peraturan yang bukan hanya membantu mensejahterakan beberapa pihak, tapi juga seluruh masyarakat.

Berdasarkan latar belakang yang sudah dibahas sebelumnya, penulis menyusun beberapa rumusan masalah dalam bentuk pertanyaan yang akan digunakan dalam penelitian ini. Rumusan masalah tersebut terdiri dari beberapa pertanyaan, yaitu "Apa yang mahasiswa ketahui tentang Marketplace?”; “Apa saja dampak positif dan negatif untuk mahasiswa?"; "Bagaimana sikap Mahasiswa muslim terhadap perkembangan Marketplace?"; dan "Bagaimana pandangan islam mengenai penggunaan Marketplace?".

Rumusan masalah yang disebutkan sebelumnya disusun agar dapat memenuhi beberapa tujuan dilakukannya penelitian ini. Diantaranya adalah untuk mengetahui apakah mahasiswa muslim indonesia mengenal Marketplace; mengetahui apa saja dampak yang dirasakan mahasiswa dalam kehidupan; mengetahui bagaimana sikap mahasiswa muslim terhadap perkembangan Marketplace; dan mengetahui bagaimana pandangan islam mengenai penggunaan Marketplace.

Dan selanjutnya penelitian ini diharapkan dapat memberikan beberapa manfaat. Manfaat tersebut kami bagi menjadi manfaat teoritis (keberfungsian penelitian bagi perkembangan ilmu pengetahuan) dan manfaat praktis (keberfungsian penelitian bagi masyarakat atau orang lain pada kesehariannya). Yang pertama, secara teoritis diharapkan penelitian ini dapat memberikan manfaat yaitu, memberikan sumbangan pemikiran kepada umat Islam terutama mahasiswa terkait dengan perkembangan Marketplace; memberikan sumbangan ilmiah dalam keilmuan ekonomi Islam terkait konsep perkembangan Marketplace, dan sebagai referensi dan pijakan pada penelitian-penelitian selanjutnya yang berhubungan dengan sikap mahasiswa muslim terhadap perkembangan Marketplace. Lalu secara praktis diharapkan penelitian ini dapat memberikan manfaat yaitu, menambah wawasan dan pengalaman bagi penulis dan pembaca tentang konsep jual-beli dalam Islam; menjadi bahan pertimbangan bagi penulis dan pembaca dalam melakukan jual-beli yang sesuai dengan aturan Islam; dan membantu mengatasi berbagai permasalahan yang terjadi terkait dengan ekonomi Islam.

Terdapat berbagai bidang di kehidupan kita, yang saling mempengaruhi satu sama lain, dan ikut mempengaruhi kehidupan kita baik secara langsung maupun tidak langsung. Karena pada dasarnya "manusia selain sebagai makhluk individual yang berjiwa dan beraga juga sebagai makhluk sosial, yaitu makhluk yang berkodrat hidup dalam masyarakat. Sebagai mahluk sosial, dalam hidupnya manusia memerlukan adanya manusia-manusia lain yang bersama-sama hidup bermasyarakat, manusia selalu berhubungan satu sama lain. Disadari atau tidak untuk mencukupi kebutuhan-kebutuhan hidupnya" (Basyir, 1993).

Salah satu bidang yang sangat familier bagi orang banyak yang bahkan dapat mempengaruhi keseharian orang-orang, dan sering di hubungkan dengan kegiatan jual beli, yaitu ekonomi. Dan semua kegiatan manusia diatur dalam agama yang sempurna, yaitu agama Islam, meliputi semua bidang tak terkecuali bidang ekonomi, atau yang biasa disebut sebagai ekonomi islam. Secara umum, ekonomi didefinisikan sebagai ilmu dan kegiatan yang memanfaatkan sumber daya yang berharga dan mengelolanya dengan prinsip produksi dan distribusi berdasarkan suatu sistem yang ada untuk kepentingan pribadi maupun bersama. Menurut M. Umer Chapra, ekonomi Islam adalah sebuah pengetahuan yang membantu upaya realisasi kebahagiaan manusia melalui alokasi dan distribusi sumber daya yang terbatas yang berada dalam koridor yang mengacu pada pengajaran Islam tanpa memeberikan kebebasan individu atau tanpa perilaku makro ekonomi yang berkesinambungan dan tanpa ketidakseimbangan lingkungan. Menurut Syed Nawab Haider Naqvi, ilmu ekonomi Islam, singkatnya merupakan kajian tentang perilaku ekonomi orang Islam representatif dalam masyarakat muslim modern (Bahtiar, 2017). Jadi kesimpulannya, ekonomi islam adalah ilmu pengetahuan yang membantu realisasi kebahagiaan manusia dengan memanfaatkan dan mengelola sumber daya yang berharga melalui proses 
produksi dan distribusi, dengan sistem atau aturannya mengacu pada hukum-hukum Islam.

Dasar hukum jual beli telah diatur dalam AlQur'an, diantaranya terdapat di dalam Q.S. An-Nisa' ayat 29: "Hai orang-orang yang beriman, janganlah kamu saling memakan harta sesamamu dengan jalan yang batil, kecuali dengan jalan perniagaan yang berlaku dengan suka sama-suka di antara kamu. Dan janganlah kamu membunuh dirimu; sesungguhnya Allah adalah Maha Penyayang kepadamu."

Seiring perkembangan zaman, banyak hal di dunia ini yang ikut berubah dan berkembang menjadi lebih efektif dan efisien, demi beradaptasi dengan zaman yang ada, tak terkecuali pada bidang teknologi dan ekonomi. Teknologi berkembang dengan sangat pesat, hingga pada saat ini sudah ditemukannya internet. Internet sangatlah memudahkan kehidupan dan kegiatan sehari-hari manusia, segala kegiatan di kehidupan ini banyak yang sudah memanfaatkan internet atau dilakukan secara online. Rahmadi (2003) dalam modul pembelajaran internet mengatakan bahwa internet merupakan sebuah sebutan untuk sekumpulan jaringan komputer yang dapat menghubungkan berbagai situs akademik, pemerintahan, komersial, organisasi, hingga perorangan. Kegiatan ekonomi juga berkembang seiring waktu dan mengikuti perkembangan yang ada yang dirasa lebih efisien dan efektif, mulai dari penggunaan sistem barter, jual beli tradisional, sampai yang sedang popular ini, yaitu dengan memanfaatkan internet atau bisa disebut dengan jual beli online (Rahmawat, 2016). Transaksi jual beli di dunia maya atau e-commerce merupakan salah satu produk internet yang merupakan sebuah jaringan komputer yang saling terhubung antara satu dengan yang lainnya. Dalam satu jaringan tersebut terdapat satu rangkaian banyak terminal komputer yang bekerja dalam satu sistem komunikasi elektronik. (Rahmawati, 2018).

Dalam melakukan kegiatan jual-beli online, para pembeli dan penjual biasanya menggunakan aplikasi tertentu yang dapat memudahkan kegiatan jual-beli. Keseluruhan aplikasi ini bisa disebut sebagai Marketplace. Marketplace merupakan media online berbasis internet (web based) tempat melakukan kegiatan bisnis dan transaksi antara pembeli dan penjual. Pembeli dapat mencari supplier sebanyak mungkin dengan kriteria yang diinginkan, sehingga memperoleh sesuai harga pasar (Assadurachman, 2017). Sedangkan bagi supplier/penjual dapat mengetahui perusahaan-perusahaan yang membutuhkan produk/jasa mereka Opiida dalam (Assadurachman, 2017).

Allah Swt berfirman dalam Alquran Surah AlBaqarah: 275: “.... Allah telah menghalalkan jual beli dan mengharamkan riba...". Jual beli dalam ayat termasuk didalamnya bisnis yang dilakukan lewat online. Namun jual beli lewat online harus memiliki syarat-syarat tertentu boleh atau tidaknya dilakukan.

Kemajuan informasi teknologi spesifikasi barang bisa dilihat terlebih dahulu baik secara gambar maupun video. Jika barang tidak sesuai dengan ciriciri yang telah disepakati pembeli boleh melakukan kyiar. Khiyar adalah memilih antara dua alternatif meneruskan untuk jual beli atau mengurungkannya. Hak untuk memilih antara kedua kemungkinan tersebut sepanjang masing-masing pihak dalam mempertimbangkan. Diperbolehkannya khiyar agar masing-masing pihak (penjual atau pembeli) tidak menyesali apa yang telah di jual atau belinya. Sebab penyesalan tersebut karena kurang hati-hati, tergesagesa atau factor lainnya (Syafei, 2000).

Batasan fikih terkait belanja online menjadi benar dan sah menurut syariat Islam yang harus diperhatikan diantaranya: 1. Barang/jasa yang dibeli harus memenuhi kriteria, yaitu barang/jasa harus halal tidak diperbolehkan berbelanja barang/jasa yang haram baik karena fisiknya seperti membeli minuman yang memabukkan maupun nonfisiknya seperti mainan yang dapat merusak moral anak-anak. Barang/jasa yang dibeli merupakan prioritas untuk dimiliki, tidak membeli barang/jasa yang tidak dibutuhkan agar terhindar dari pemubaziran, barang yang dibeli jelas kriteria dan spesifiknya, pembeli diberikan hak khiyar untuk membatalkan jual beli atau menerima kerelaan saat barang yang diterima tidak sesuai dengan pesanan. 2. Cara membelinya dengan jual beli tunai maupun jual beli tidak tunai (barang diserahkan secara tunai, sedangkan harga diterima oleh penjual secara tidak tunai) berdasarkan hasil keputusan Majma' AlFiqh Al-Islami (Divisi Fikih Organisasi Kerja sama Islam/OKI) No. 51 (2/6) 1990 yang membolehkan jual beli tidak tunai dan Fatwa DSN MUI No.04/DSNMUI/IV/2000 tentang Murabahah. 3. Diprioritaskan berbelanja di tempat/lapak yang memberikan kontribusi terhadap penguatan ekonomi masyarakat dan tidak melanggar peraturan perundang-undang. 4. Diniatkan berbelanja untuk beribadah kepada Allah SWT, sehingga setiap berbelanja itu untuk keperluan ibadah kepada Allah SWT. 
Dalam islam jual beli online termasuk dari akad jual beli salam, yang ma bai' as-salam merupakan pembelian barang yang diserahkan dikemudian hari, sedangkan pembayarannya di muka. Bai' as-salam juga disebut dengan akad pesanan, yang mana penjual dan pembeli tidak bertemu secara langsung, hanya melakukan transfer untuk pembayaran dan menggunakan internet untuk melakukan transaksi antara kedua belah pihak. oleh karena itu hukum bai' as-salam diperbolehkan dalam islam.

\section{METODE PENELITIAN}

Pendekatan yang digunakan dalam penelitian ini adalah pendekatan kualitatif, yang merupakan prosedur kerja untuk menghasilkan data deskriptif berupa kata-kata tertulis atau lisan dari orang-orang dan perilaku yang dapat diamati. Menurut Moleong dalam (Sugianto, 2020), penelitian kualitatif adalah penelitian yang bermaksud untuk memahami fenomena tentang apa yang dialami oleh subjek penelitian misalnya perilaku, persepsi, motivasi, tindakan, dll secara holistic, dan dengan cara deskripsi dalam bentuk kata-kata dan bahasa, pada suatu konteks khusus yang alamiah dan dengan memanfaatkan berbagai metode alamiah. Penelitian ini dilakukan ke Perguruan Tinggi Umum dan Organisasi Islam (MUI). Subjek penelitian merupakan sumber data yang dimintai informasinya sesuai dengan masalah yang diteliti. Dalam penelitian ini yang menjadi sumber data adalah Mahasiswa Muslim dan Sekretaris Umum (MUI). Adapun fokus masalah dalam penelitian ini adalah sikap Mahasiswa Muslim terhadap perkembangan Marketplace. Teknik pengumpulan data yang digunakan dalam penelitian ini adalah teknik observasi, wawancara dan angket.

Menurut Sugiyono (2011: 80), populasi adalah wilayah generalisasi yang terdiri atas obyek/subyek yang mempunyai kualitas dan karakteristik tertentu yang ditetapkan oleh peneliti untuk dipelajari dan kemudian ditarik kesimpulannya. Populasi dalam penelitian ini adalah 100 Mahasiswa Muslim Perguruan Tinggi di Indonesia.

Metode pengumpulan data adalah cara yang dipakai dalam pengumpulan data, sedangkan alat pengumpulan data adalah alat bantu yang digunakan dalam pengumpulan data (Mohamad \& Rahman, 2012).

Dalam penelitian ini, kami menggunakan angket atau kuisioner dalam bentuk google form dan wawancara. Menurut (Mohamad \& Rahman, 2012) angket merupakan pertanyaan-pertanyaan penelitian yang direka khusus untuk mengumpulkan data kajian. Sedangakan wawancara adalah salah satu cara untuk mengumpulkan informasi yang utama dalam kajian pengamatan. Ia dilakukan dengan tanya jawab secara lisan dan jawaban disimpan secara tertulis, melalui rekaman kaset, video, atau media elektronik lain (Mohamad \& Rahman, 2012).

Pengambilan data dari kuisioner yang kami lakukan melalui media google form, berisi 3 pertanyaan data diri responden yaitu: 1 . Nama; 2 . Jenis Kelamin; 3. Instansi. Setelah mengisi data diri, responden diberikan 9 pertanyaan mengenai Marketplace yaitu: 1. Apa anda tahu Marketplace itu apa?; 2. Jika tahu coba jelaskan!; 3. Apakah anda pernah menggunakannya (membeli, menjual, menjadikan referensi berbelanja, dll)?; 4. Seberapa sering anda menggunakannya dalam satu bulan?; 5. Di posisi apakah anda dalam menggunakan Marketplace?; 6. Apa yang anda ketahui tentang jual beli dalam Marketplace?; 7. Menurut anda, bagaimana pandangan islam mengenai jual-beli dengan menggunakan Marketplace?; 8. Sistem jual-beli di Marketplace yang anda gunakan, seperti apa? (Contohnya: cara membayar seperti apa yang anda gunakan, lalu proses transaksi seperti apa yang anda gunakan); 9. Lalu apakah ada pengaruhnya terhadap kehidupan sehari-hari anda? Jelaskan!

Kemudian kami melakukan wawancara langsung dengan pihak MUI provinsi jawa barat, dengan mengajukan 4 pertanyaan yaitu: 1 . Jual beli dalam islam seharusnya seperti apa?; 2. Menurut narasumber, apakah sah melakukan jual-beli menggunakan Marketplace?; 3. Bagaimana pandangan narasumber terhadap mahasiswa yang berdagang di Marketplace?; 4. Tips menggunakan Marketplace agar tetap sesuai dengan syariat Islam?.

Menurut (Mohamad \& Rahman, 2012) analisis data adalah kegiatan tentang bagaimana data yang telah dikumpulkan itu diolah, diklasifikasi, dibedakan, dan kemudian dipersiapkan untuk dipaparkan. Dalam artikel ini, kami menggunakan analisis data kualitatif karena menggunakan data kualitatif. Proses analisis mengalir dari tahap awal hingga tahap penarikan kesimpulan hasil studi (Salim, 2006).

\section{HASIL DAN PEMBAHASAN}

Islam merupakan agama yang sempurna, di dalamnya mengatur segala kegiatan kita, tak terkecuali pada bidang teknologi dan ekonomi. Kita 
sebagai manusia yang tak luput dari kesalahan, membutuhkan adanya bimbingan dari Allah SWT agar kita tetap berada di jalan yang benar. Seiring berkembangnya zaman, banyak hal yang ikut berkembang termasuk pada bidang teknologi. Islam merupakan agama yang terbuka terhadap adanya perkembangan, karena itu kita dapat mencari solusi dari berbagai permasalahan masa kini, termasuk pada konsep jual-beli online dan Marketplace.

\section{a. Apa yang mahasiswa ketahui tentang Marketplace?}

Pada 2019 ini, jumlah pengguna e-commerce di Indonesia diproyeksikan akan mencapai 168,3 juta pengguna dan terus meningkat mencapai 212,2 juta pada 2023 (Dahuri, 2019). Dari data tersebut terlihat bahwa pengguna e-commerce sangatlah banyak. Kemudian diperkirakan pengguna yang aktif dalam berbelanja online ada pada kisaran usia 16 sampai 64 tahun ada sebanyak $66 \%$ dari total penduduk, yaitu sekitar 179,7 juta jiwa. (Nurdian, 2020). Hal ini berarti pertumbuhan penggunaan $e$-commerce yang termasuk didalamnya ada Marketplace, sudah sangatlah popular. Terbukti dengan banyaknya pengguna di Indonesia ini sendiri. Bahkan selama pandemi ini, nilai transaksi secara digital di bulan Agustus sudah meningkat sebesar $33,8 \%$. Jauh lebih banyak dari bulan sebelumnya yang ada dikisaran 24,42 \% (Miftahudin, 2020). Tentu saja ini adalah hal yang luar biasa, karena disaat pandemi sekarang, perekonomian menemukan jalannya tersendiri agar bisa tetap tumbuh.

Dari data yang kami peroleh, didapat 100 responden dengan rincian sebagai berikut. 68 responden perempuan dan 32 responden laki-laki. 97 diantaranya adalah mahasiswa muslim dan 3 orang sisanya tidak mengisi pertanyaan identitas dengan benar.

Berdasarkan pertanyaaan-pertanyaan dalam kuisioner didapat hasil sebagai berikut.

Diagram 1. Pengetahuan tentang Marketplace

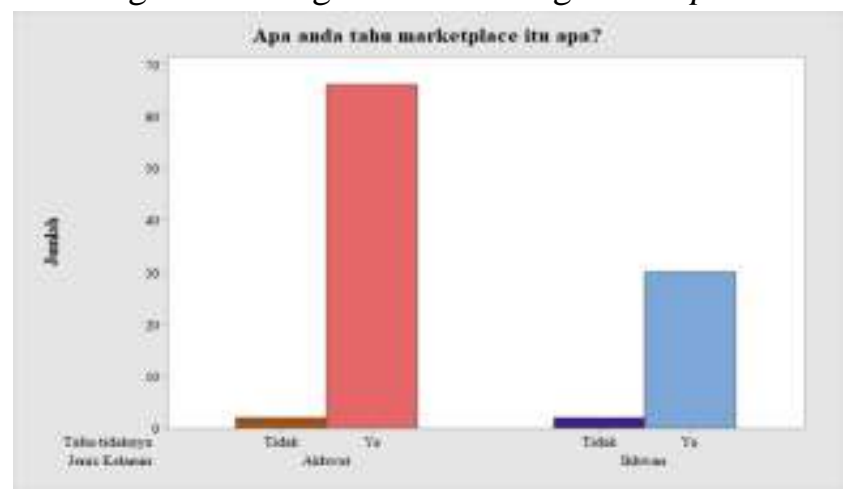

Dari data tersebut didapat, 96 orang mengetahui apa itu Marketplace dan 4 orang tidak mengetahuinya. Jika dibagi dalam jenis kelamin, ada sebanyak 66 responden yang mengetahui dan 2 tidak. Untuk responden laki-laki ada sebanyak 30 responden yang mengetahui dan 2 orang tidak. Hal ini artinya Sebagian besar responden sudah mengetahui apa itu Marketplace.

Kemudian jawaban-jawaban mengenai apa itu Marketplace ada beragam, tetapi yang dominan adalah Marketplace sebagai tempat jual beli online. Untuk rinciannya kami kelompokan menjadi tempat jual beli secara online; memberikan contoh Marketplace seperti: Shopee, Bukalapak, Tokopedia, dll; menyamakan dengan konsep tempat transaksi konvensional seperti: pasar online, department store online, dll; dan pihak ketiga yang menyediakan tempat dan fasilitas pembayaran.

Kemudian dari jawaban-jawaban responden, mereka lebih familiar dengan sebutan online shop/olshop dibandingkan dengan Marketplace itu sendiri.

Selanjutnya ada pertanyaan mengenain pernah tidaknya responden menggunakan Marketplace, kemudian didapat kan hasil;

Diagram 2. Pernah tidaknya responden menggunakan Marketplace

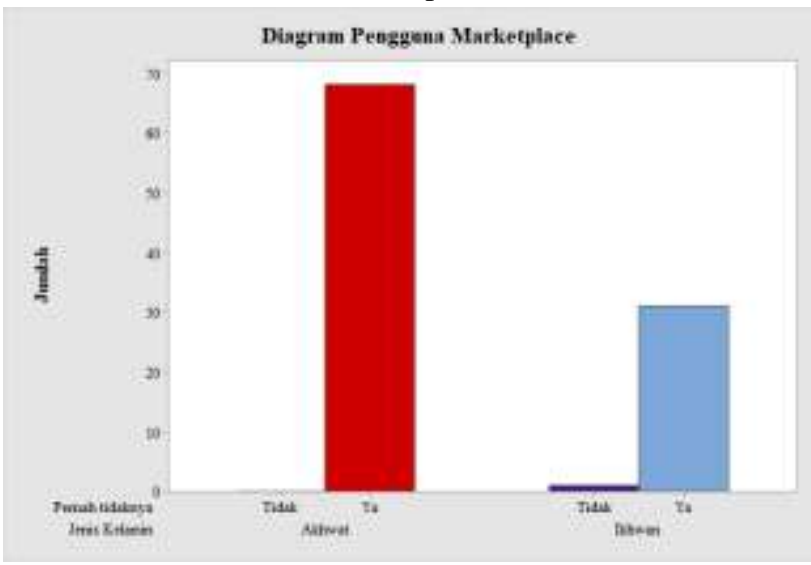

Dari hasil tersebut, ternyata hanya ada 1 orang saja yang belum pernah menggunakan Marketplace. Padahal sebelumnya ada 4 orang yang tidak mengetahui apa itu Marketplace. Sebanyak 68 responden perempuan mengaku pernah menggunakan Marketplace, sedangkan untuk responden laki-laki ada sebanyak 31 orang yang mengaku pernah menggunakan Marketplace.

Selanjutnya untuk frekuensi penggunaan Marketplace tiap responden didapat hasil sebagai berikut: 
Diagram 3. Frekuensi responden dalam menggunakan Marketplace dalam 1 bulan

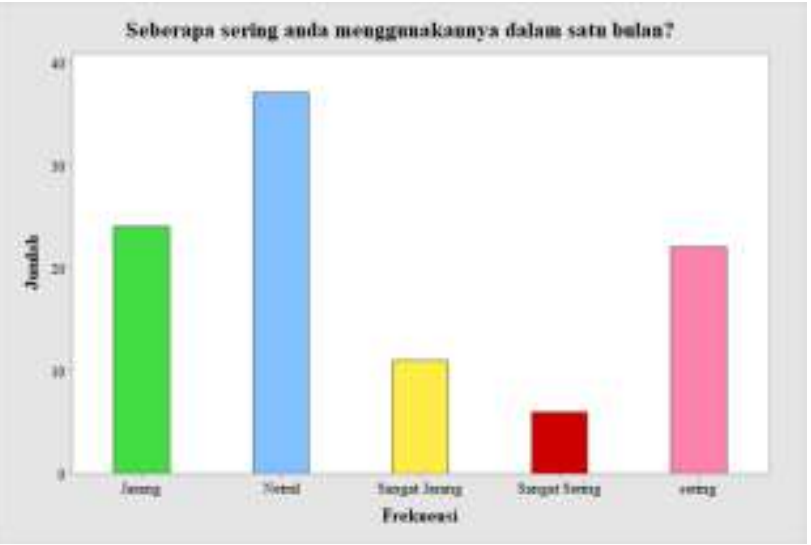

Dari data tersebut, ada 6 orang yang sangat sering menggunakannya, 22 orang yang sering menggunakannya, 37 orang mengaku netral, 24 orang jarang menggunakannya, dan 11 orang sangat jarang menggunakannya. Jika dilihat, kebanyakan responden mengaku jarang menggunakan Marketplace. Daripada yang sering menggunakannya. Sedangkan sebanyak 37 orang lebih memilih untuk netral.

Dari hasil hasil tersebut, Sebagian besar responden mengetahui apa itu Marketplace dan menggunakannya juga, tetapi frekuensi penggunannya kebanyakan tidak terlalu sering.

\section{b. Dampak Positif dan Negatif untuk Mahasiswa Muslim apa saja?}

Marketplace merupakan solusi yang tercipta dari pesatnya perkembangan teknologi informasi dan internet yang menggempur industri perdagangan. Meningkatnya Marketplace di Indonesia hingga saat ini masih menjadi perbincangan hangat dikalangan masyarakat khususnya Mahasiswa yang identik dengan hal-hal instan dalam mencari informasi maupun untuk kegiatan bisnis tanpa mengeluarkan banyak tenaga dalam pemenuhan kebutuhan. Namun tetap saja, dibalik kemudahan dan kecepatan belanja online terdapat dampak positif maupun negatif yang dirasakan oleh pengguna.

Dampak positif dari belanja online menggunakan Marketplace yaitu belanja menjadi lebih praktis; bisa membandingkan harga dengan mudah dari satu online shop ke online shop-lain; hemat tenaga dan waktu; tidak perlu berjalan dari satu toko ke toko lain untuk mendapatkan barang yang diinginkan; bisa mendapatkan barang dari mana saja, dari luar kota bahkan luar negeri; harga barang biasanya lebih murah; dan membantu perekonomian pedagang kecil.

Selain dampak positif, tentu ada juga dampak negatif dari belanja online menggunakan
Marketplace, yaitu kualitas barang yang tidak sesuai dengan gambar; barang yang diterima cacat atau rusak ketika barang dalam pengiriman; tidak bisa membedakan barang asli atau tiruan; sering terjadi penipuan, setelah uang ditransfer, barang tidak diterima; dan menimbulkan perilaku konsumtif.

\section{c. Bagaimana sikap Mahasiswa muslim terhadap perkembangan Marketplace?}

Setiap orang memiliki cara pandang yang berbeda terhadap suatu masalah, begitu juga dengan sikap yang mereka ambil untuk menghadapi suatu masalah. Untuk itu bagaimana sikap mahasiswa menghadapi perkembangan marketplace ini, apakah mereka diam saja? Atau ikut dalam memanfaatkan perkembangan ini. Dari data yang kami peroleh:

Diagram 4. Peran mahasiswa dalam marketplace

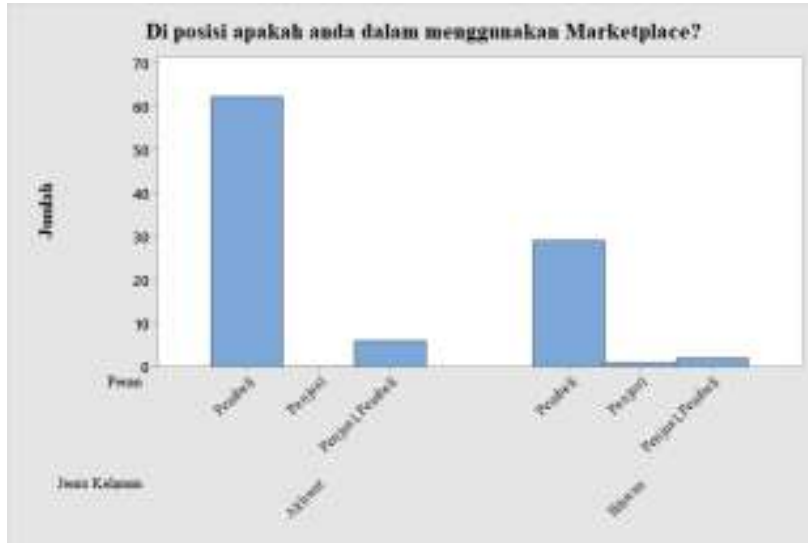

Dari hasil pada diagram 4., ada 29 laki-laki dan 62 perempuan yang memanfaatkan kemudahan dalam marketplace sebagai konsumen. Ada sebanyak 1 orang laki-laki saja yang hanya menjadi penjual. lalu ada 2 laki-laki dan 6 orang perempuan yang menjadi penjual sekaligus pembeli dalam marketplace. Hal ini berarti mahasiswa lebih dominan menjadi pembeli daripada menjadi penjual. Dan hal ini memang sejalan dengan rasio jumlah wirausahawan terhadap jumlah populasi Indonesia yang masih kurang dari $3 \%$, hal ini diungkapkan oleh sandiaga uno dalam (Rantung, 2020).

Selain membuat pertanyaan di kuisioner, kami juga menanyakannya kepada MUI provinsi Jawa Barat. Dari hasil wawancara dengan pihak MUI yang diwakili oleh Drs. H.M. Rafani Akhyar, M. S selaku sekretaris umum Majelis Ulama Indonesia Provinsi jawa Barat, mengatakan bahwa dalam Islam berdagang itu penting. Namun disebutkan juga secara langsung dalam Al-Qur'an, untuk tidak mengurangi timbangan dan takaran. Oleh karena itu, kita sebagai mahasiswa boleh saja untuk berdagang, asalkan kita menerapkan prinsip Islam, yaitu menerapkan 
kejujuran. Jangan sekali-kali membohongi. InsyaAllah dengan demikian aman. Karena disebutkan juga dalam hadits hadits, kalau para pelaku ekonomi tidak jujur, maka akan berpengaruh pada kehidupan yang lebih luas.

Lalu bagi penjual dan pembeli yang menggunakan marketplace, terdapat beberapa tips agar melakukan kegiatan jual-beli di marketplace yang sesuai syariat Islam. Menurut pihak MUI, kalau seumpamanya kita ingin melakukan akad jual-beli di marketplace, namun tidak bisa bertemu langsung antara penjual dan pembeli, maka bisa diantisipasi dengan kedua pihak berniat untuk melakukan akad jual-beli. Karena pada intinya akad itu dilakukan untuk kesempurnaan walaupun tidak bertatap muka secara langsung. Kemudian yang terpenting harus yakin dulu, karena membeli di marketplace itu terdapat 2 kemungkinan, yaitu bisa sesuai dengan harapan dan tidak, maka sadari hal itu semua (punya sikap mental yang bagus, sudah siap kecewa).

\section{d. Pandangan islam mengenai jual beli menggunakan marketplace}

Untuk menjawab pertanyaan ini, kami menanyakannya kepada MUI provinsi Jawa barat dan membuat pertanyaan di kuisioner. Dari hasil wawancara dengan pihak MUI yang diwakili oleh Drs. H.M. Rafani Akhyar, M. S selaku sekretaris umum Majelis Ulama Indonesia Provinsi jawa Barat, mengatakan bahwa prinsip jual beil dalam islam itu tidak boleh ada manipulasi, artinya harus jujur. Kemudian dari beberapa pendapat yang ada, dalam jual beli harus jelas barang, penjual, pembeli dan juga akadnya. Karena sekarang perkembangan teknologi sudah sangat pesat, munculah yang namanya marketplace. Yang fungsi nya sebagai sarana, sama dengan pasar. Sedangkan pasar itu waktu zaman nabi adalah pusat ekonomi. Dalam pasar tradisional, semuanya serba jelas. Kemudian untuk di marketplace yang terpenting adalah prinsip kejujuran karena barangnya tidak ada secara langsung. Bisa jadi barang yang ditampilkan berbeda dengan yang dikirim nanti. Tentu hal ini yang tidak boleh. Untuk akadnya, ada beberapa pendapat, ada yang harus diucapkan Ketika berhadapan langsung dan ada juga yang tidak perlu berhadapan secara langsung. Lalu untuk kejelasan barangnya, beliau berkata "Mungkin yang jadi tinjauan sekarang adalah kejelasan barang, nah sekarangkan hanya ditampilkan dalam gambar tidak sesuai, ini yang problem. Ini termasuk unsur ghoror (yang membeli spekulasi, yang menjualnya penipuan). Mungkin, kalau barang yang jelas brandnya itu pasti udah jelas spesifikasinya. Di satu sisi, teknologi ini memudahkan, tapi di sisi lain ya itu bisa dimanfaatkan dengan yang tidak baik."

Jual beli dalam marketplace, menurut MUI sahsah saja. Prinsipnya harus jujur, adil, amanah. Sebab ada dalam hadits "Kejujuran para pedagang, dunia ini akan indah kalau pedagangnya itu jujur. Pedagang itu pelaku ekonomi”. Jika dalam marketplace ini banyak ketidakjujuran, menurut mui akan terjadi kerawanan karena nanti orang-orang akan protes. Katanya masih belum tahu tentang aturan yang menjamin konsumen supaya tidak dirugikan. Beliau pun berkata bahwa sering mendapat keluhan tentang kondisi barang yang berbeda. Tetapi hal ini tidak hanya di marketplace saja, bahkan di mall pun bisa terjadi.

\section{KESIMPULAN DAN SARAN}

\subsection{Kesimpulan}

Berdasarkan hasil analisis dan pembahasan yang telah diuraikan sebelumnya, maka diperoleh beberapa kesimpulan. Pertama sebagian besar mahasiswa sudah mengetahui apa itu marketplace dan mengaku pernah menggunakannya, tetapi intensitas penggunaannya tidak terlalu sering.

Kemudian ada dampak positif yang didapat dari penelitian ini, yaitu belanja menjadi lebih praktis, bisa membandingkan harga dengan mudah dari satu online shop ke online shop-lain, hemat tenaga dan waktu, tidak perlu berjalan dari satu toko ke toko lain untuk mendapatkan barang yang diinginkan, bisa mendapatkan barang dari mana saja, dari luar kota bahkan luar negeri, harga barang biasanya lebih murah, dan membantu perekonomian pedagang kecil.

Sedangkan untuk dampak negatifnya adalah kualitas barang yang tidak sesuai dengan gambar, barang yang diterima cacat atau rusak ketika barang dalam pengiriman. Tidak bisa membedakan barang asli atau tiruan, sering terjadi penipuan, setelah uang ditransfer, barang tidak diterima, dan menimbulkan perilaku konsumtif.

Selain dari dampak-dampak tersebut lebih banyak mahasiswa yang memilih memanfaatkan kemudahan dari marketplace sebagai pembeli, karena dapat mempermudah mencari informasi barangbarang yang diinginkan. Selain itu, bisa menghemat tenaga dan waktu, sehingga sangat berpengaruh dalam kehidupan sehari hari

Menurut pandangan MUI, transaksi melalui marketplace itu boleh boleh saja, asalkan memenuhi 
prinsip $^{2}$ seperti kejujuran, amanah, jelas barang, akad, penjual dan pembeli. Begitu pula dengan pandangan Mahasiswa Perguruan Tinggi, transaksi melalui Marketplace diperbolehkan, dengan syarat tidak boleh menyimpang dari hukum atau syariat islam. Karena inti dari transaksi jual-beli haruslah suka sama suka dan tidak merugikan kedua belah pihak.

\subsection{Saran}

Berdasarkan penelitian yang telah dilakukan, terdapat beberapa saran yang mungkin bermanfaat bagi peneliti selanjutnya, yaitu perluas lagi jangkauan responden yang digunakan, perbanyak lagi populasi yang akan diteliti, perbanyak pandangan dari sisi penjual, wawancarai ormas islam besar yang lainnya.

\section{UCAPAN TERIMA KASIH}

Syukur Alhamdulillah senantiasa penulis panjatkan kehadirat Allah SWT. atas segala limpahan rahmat, inayah, taufik serta hidayahnya sehingga kami dapat menyelesaikan penyusunan makalah ini dengan baik. Penulis juga menyampaikan terima kasih yang sebesar-besarnya kepada seluruh pihak yang sudah memberikan dukungan dan doa sehingga penulis dapat menyelesaikan penelitian ini.

\section{REFERENSI}

Arif, M. (2012). Pendidikan Agama Islam InklusifMultikultural. Jurnal Pendidikan Islam, 1-18.

Assadurachman, A. (2017). Marketplace Barang Bekas Kos Yogyakarta. Yogyakarta: Universitas Islam Indonesia.

Bahtiar, M. Y. (2017). Pengaruh Label Halal Pada Produk Dalam Kemasan Dan Harga Terhadap Keputusan Pembelian (Studi Pada Produk Kecantikan Di Supermarket Chandra Dan Ramayana Kota Bandar Lampung). Bandar Lampung, Lampung, Indonesia: UIN Raden Intan Lampung. Diambil kembali dari Repository UIN Raden Intan Lampung.

Basyir, A. A. (1993). Asas-Asas Hukum Muamalat (Hukum Perdata Islam) (Revisi ed.). Yogyakarta: Fakultas Hukum UII.

Dahuri, D. (2019, Oktober 27). Pengguna ECommerce di Tanah Air akan Capai 168,3 Juta. Diambil kembali dari Media Indonesia: https://mediaindonesia.com/read/detail/267857pengguna-e-commerce-di-tanah-air-akan-capai1683-juta
Miftahudin, H. (2020, Oktober 13). Agustus 2020, Nilai Transaksi Uang Elektronik Tumbuh 33,8\%. Diambil kembali dari Medcom.id: https://www.medcom.id/ekonomi/keuangan/ak WLoZXK-agustus-2020-nilai-transaksi-uangelektronik-tumbuh-33-8

Mohamad, M., \& Rahman, M. T. (2012). PENGANTAR METODE PENELITIAN. Yogyakarta: LaksBang Pressindo.

Nurdian, G. (2020, April 27). Graha Nurdian. Diambil kembali dari E-Commerce Indonesia Tahun 2020. Era Digital Mendominasi: https://grahanurdian.com/e-commerceindonesia-tahun-2020/

Nuryana, Z. (2018). Pemanfaatan Teknologi Informasi dalam Pendidikan Agama Islam. Jurnal Tamaddun, 75-86.

Rahmawat, F. N. (2016). “ OPTIMALISASI PENGGUNAAN INTERNET TERHADAP PENINGKATAN PRESTASI BELAJAR PESERTA DIDIK” Studi Deskriptif pada Mata Pelajaran PKn Kelas XI di SMA Negeri 9 Bandung. Bandung: Universitas Pasundan.

Rahmawati, K. (2018). Tinjauan Hukum Bisnis Syariah Terhadap Jaminan Dalam Transaksi Online. Banjarmasin: UIN Antasari Banjarmasin.

Rantung, F. (2020, September 8). Rasio Wirausaha di Indonesia Tertinggal Dibanding Negara Tetangga. Diambil kembali dari Sindonews.com: https://ekbis.sindonews.com/read/158312/34/ras io-wirausaha-di-indonesia-tertinggal-dibandingnegara-tetangga-1599574154

Salim, A. (2006). Teori dan Paradigma Penelitian Sosial. Yogyakarta: Tiara Wacana.

Sugianto, O. (2020, April 13). Binus University. Diambil kembali dari Penelitian Kualitatif, Manfaat dan Alasan Penggunaan: https://binus.ac.id/bandung/2020/04/penelitiankualitatif-manfaat-dan-alasan-penggunaan/

Syafei, R. (2000). Fiqih Muamalah. Bandung: Pustaka Setia. 


\section{LAMPIRAN}

\section{Wawancara dengan MUI}

a. Bagaimana sudut pandang islam terkait jual beli?

Prinsip jual beli dalam islam yang terpenting itu:pertama, tidak boleh ada manipulasi. Artinya harus dengan kejujuran. Kemudian dari beberapa pendapat, kalau jual beli dalam islam itu harus jelas barangnya, jelas penjualnya, jelas pembelinya dan bahkan harus pake akad. Sekarang, menurut saya perkembangan teknologi sudah sangat pesat, sehingga munculnya Marketplace. Nah, Marketplace itu kan sebuah sarana, fungsinya sama dengan pasar. Pada zaman nabi, pasar itu pusat ekonomi. Nah, hanya pasar itu tradisional ya, pembeli dengan penjual berhadapa2an, barangnya memang ada, akadnya jelas. (Nyanggakeun barangna, nampi artosna)

Nah,sekarang di Marketplace, yang terpenting menurut saya adalah prinsip kejujuran di antara pembeli dan penjual itu harus ada, karena barangnya tidak ada. Bisa jadi barang yang ditampilkan dengan barang yang dikirim iti berbeda, nah ini yang tidak boleh. Kemudian akad, pendapat itu ada yang harus diucapkan secara berhadap2an ada juga yang tidak harus berhadap2an gitu ya. Kemudian, soal barangnya harus jelas dan uangnya pun harus jelas. Mungkin yang jadi tinjauan sekarang adalah kejelasan barang, nah sekarangkan hanya ditampilkan dalam gambar tidak sesuai, ini yang problem. Ini termasuk unsur ghoror (yang membeli spekulasi, yang menjualnya penipuan). Mungkin, kalau barang yang jelas brandnya itu pasti udah jelas spesifikasinya. Di satu sisi, teknologi ini memudahkan, tapi di sisi lain ya itu bisa dimanfaatkan dengan yang tidak baik.

b. Menurut bapa, apakah sah melakukan jual-beli menggunakan Marketplace?

Sah-sah saja. Berarti tinggal kembali pada pelaku, baik penjual maupun pembeli. Prinsipnya harus jujur, tidak boleh berbohong, adil, amanah. Sebab ada dalam hadits "Kejujuran para pedagang, dunia ini akan indah kalau pedagangnya itu jujur. Pedagang itu pelaku ekonomi. Nah, ini juga fenomena Marketplace kalau marak ketidakjujuran, saya yakin akan memicu kerawanan (karena nanti orang akan protes). Saya belum tahu aturan regulasin hukumnya ya pemerintah bagaimana menjamin konsumen supaya tidak dirugikan dalam transaksinya. Mungkin hanya mengacu pada perlindungan konsumen secara umum. Saya juga banyak mendapatkan keluhan 'loh kok, ini kenapa barangnya kaya gini” (Tidak hanya di Marketplace, bahkan di mall biasa pun kadang suka terjadi)

c. Menurut bapak, pandangan bapak terhadap mahasiswa yang berdagang di Marketplace bagaimana?

Ya itu, silahkan saja. Cuma kalau mau menerapkan prinsip islam terapkan kejujuran. Jangan sekalikali membohongi. InsyaAllah dengan demikian aman. Karena udah begitu di hadits yang tadi. Kalau para pelaku ekonomi tidak jujur ya efeknya pada kehidupan yang lebih luas.

Dalam Al Quran yang disebut langsung itu kan jangan mengurangi timbangan, takaran. Nah, yang tadi memfoto barang yang tidak sesuai dengan yang aslinya itu termasuk pada pengurangan takaran. Itu problemnya disitu menurut saya.

d. Tips membeli atau menjual di Marketplace yang sesuai dengan syariat islam

Jadi, kalau memang kita upamanya mau melaksanakan akad, karena kan tidak ketemu langsung dengan penjualannya ya diniatkan, kemudian si penjualnya juga. Ya Pada intinya akad itu dilakukan untuk kesempurnaan walaupun tidak bertatap muka secara langsung. (Terima kasih, dll). Kemudian yang terpenting harus yakin dulu. Sekarang kan orang udah tau, beli di Marketplace itu bisa 2 kemungkinan, yaitu bisa sesuai dengan harapan dan tidak, maka sadari hal itu semua (Punya sikap mental yang bagus, sudah siap kecewa). Makanya, kalau saya, selagi masih bisa jalan mendatangi warung/toko ya langsung. 


\section{Surat izin}

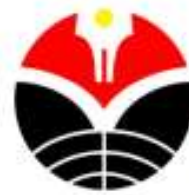

\section{KEMENTERIAN PENDIDIKAN DAN KEBUDAYAAN UNIVERSITAS PENDIDIKAN INDONESIA} FAKULTAS PENDIDIKAN MATEMATIKA DAN ILMU PENGETAHUAN ALAM

Jalan : Dr. Setiabudhi Nomor 229 Bandung 40154

Telepon/Fax. (022) 2001108, 2013163 Ext 4632

Website : fpmipa.upi.edu

\begin{tabular}{|c|c|}
\hline Nomo & : $\quad 7451 / \mathrm{UN} 40 . \mathrm{A} 4 / \mathrm{KM} / 2020$ \\
\hline Lampiran & : 1 berkas \\
\hline $\mathrm{Hal}$ & : Permohonan Izin Observas \\
\hline
\end{tabular}

Yth. Kepala MUI Provinsi Jawa Barat

di

Tempat

Bersama ini kami sampaikan bahwa mahasiswa Fakultas Pendidikan Matematika dan Ilmu Pengetahuan Alam Universitas Pendidikan Indonesia di bawah ini,

$\begin{array}{ll}\text { Nama } & \text { Rifki Candra Nugraha } \\ \text { NIM } & : 1803758 \\ \text { Program Studi } & : \text { Pendidikan Matematika }\end{array}$

akan melakukan Observasi di tempat yang Bapak/lbu pimpin. Sehubungan dengan hal tersebut, kami mohon kiranya Bapak/lbu dapat memberikan izin kepada mahasiswa bersangkutan untuk melakukan kegiatannya.

Besar harapan kami, Bapak/lbu dapat memberikan izin kepada mahasiswa bersangkutan untuk melakukan kegiatan tersebut.

Atas perhatian dan bantuan Bapak/lbu, kami ucapkan terima kasih.

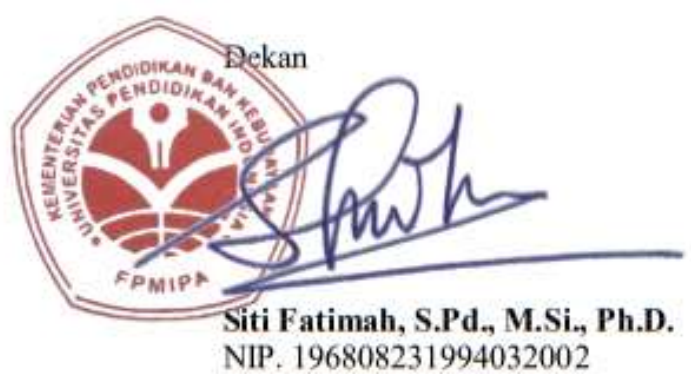

